\title{
Earnings Management and Stock for Stock Mergers
}

\author{
Chu Chen \\ Texas A\&M University-Commerce
}

This study investigates the relationship between stock for stock mergers and three earnings management methods: (1) accrual-based earnings management; (2) real earnings management; and (3) misclassification of items within the income statements. The findings show that stock for stock merger firms in the year of mergers are more likely to use accrual-based and real earnings management instead of classification shifting. In addition, this study develops an aggregate earnings quality index and compares future operating and stock market performance based on the earnings quality index.

\section{INTRODUCTION}

In a stock for stock merger, the acquiring firm exchange its stock for the stock of the target firm at the predetermined rate. Therefore, on the announcement date, the higher of the stock price of the acquiring firm, fewer number of shares must be issued to reach the predetermined rate. The relationship between the acquiring firm stock price and shares issued in a merger provides incentives for the mangers of the acquiring firm to manage earnings upward, in order to reach a higher stock price. Previous research (Erickson \& Wang, 1999; Louis, 2004) shows that the acquiring firm manages accruals before the stock for stock merger in order to reduce the cost of acquiring the target firm. According to Erickson and Wang (1999), the market always expects that the acquiring firm to manipulate its earnings upward preceding a stock for stock merger announcement. This may lead to a discount of the acquiring firm's stock on the announcement of a stock for stock merger. Therefore, the best response for the acquiring firm is to manage its earnings upward because investors discount its stock price anyway.

This study examines whether acquiring firms attempt to increase their stock price before a stock for stock merger. There are three ways to manage earnings: (1) accrual-based earnings management; (2) real earnings management; and (3) classification shifting within the income statements. Firms can use one or all methods above to manipulate earnings. Bhojraj et al. (2010) point out that managers are likely to substitute among the different methods depending on their circumstances. Previous studies addressing the earnings management on the stock for stock merger only focus on the accrual-based earnings management (Erickson \& Wang, 1999; Louis, 2004). Therefore, in order to fill the gap, this study is to investigate whether the firms employ the other two methods in the year of the stock for stock merger. The results indicate that firms involved with stock for stock merger have higher discretional accruals and lower discretional expenses. However, no evidence shows that firms employ classification shifting during the year of stock for stock mergers. Therefore, further study in this paper restricts the discussion to only accrual-based and real earnings management. 
In addition, this study examines the operating performance of firms with stock for stock mergers. The results indicate that high earnings quality firms outperform the low earnings quality firms in terms of return on assets up to three year after the stock for stock merger. The results also reveal that in one year or less firms with low earnings quality forecast have stock returns better than or equal to firms with high earnings quality. However, this reverses in three years, and high earnings quality firms have stock returns marginally better than firms with low earnings quality.

The remainder of the paper is organized as follows. Section 2 discusses motivation and hypothesis. Section 3 presents the research design. Section 4 provides the data and sample selection. Section 5 presents empirical results, and section 6 concludes.

\section{MOTIVATION AND HYPOTHESIS}

Earnings management is defined by Healy and Wahlen (1999, p. 368) as "when managers use judgment in financial reporting and in structuring transactions to alter financial reports to either mislead some stakeholders about the underlying economic performance of the company or to influence contractual outcomes that depend on reported accounting numbers." In other words, accounting is not a perfect science and allows for discretion in choosing how to report companies' financial status. Therefore, a particular earning result can be achieved by using discretional choices.

Prior accounting research has provided evidence of earnings management (i.e. Healy, 1985 \& Kasznik, 1999). One means of managing earnings is to manipulate accruals. For example, managers can change their estimation about bad debt expenses and delay asset write-offs. This allows managers to borrow earnings from future periods through the acceleration of revenues or deceleration of expenses. According to Philips et al. (2003), the cost of manipulating accruals may suffer a one-to-one earning reduction in the future.

A second means of managing earnings is the real earnings management, which refers to the manipulation of real activities, such as decreasing discretionary or advertising expenses (Dechow \& Sloan 1991; Roychowdhury 2006). Managers may choose real earnings management to avoid reporting losses (Roychowdhury 2006), to maintain positive earnings trends (Bartouv et al. 2002), and to protect their wealth tied to equity compensation (Bens et al. 2002). Accrual-based earnings management and real earnings management are fundamentally different instruments of earnings management. Accrual-based earnings management involves inter-temporal shifting of income, while real earnings management alters real activity levels that may affect future performance. Therefore, real earnings management may be more costly. For example, a company may increase net income by reduce current advertising expense. This may affect that company's future performance.

A third possible way to manipulate earnings is the misclassification of items within the income statements. The definition of classification shifting is "the deliberate misclassification of items within the income statement" (McVay, 2006, p.501). For example, managers may shift the operating expenses to discontinued operation section to inflate the core earnings, or managers may allocate the normal legal expense as a special item in order to inflate the core income. Different from the two methods discussed above, classification shifting bears less costs in that there is no future income reverses and no impact on firms' future cash flow. In addition, classification shifting is less likely to draw auditor or regulatory scrutiny since GAAP net income does not change. Previous research has documented the evidence and viability of using classification shifting. For example, McVay (2006) finds that managers use the classification shifting method to meet the analyst forecast earnings benchmark. By using quarterly data, Fan et al. (2009) indicate that classification shifting is more likely in the fourth quarter than in interim quarters.

According to Botsari and Meeks (2008), approximately $20 \%$ to $30 \%$ of mergers are stock for stock mergers. A stock for stock merger usually follows three steps: negotiating the terms, reaching the agreement, and exchanging the acquiring firm's stock for the target firms' stock or assets. There are two important dates involved in the three steps, the announcement date and the effective date. The announcement date is defined as the date when the intention of a merger is reported to the public, while 
the effective date is the date when the deal is completed and reported to the public. Due to the quick response of the stock market to the earnings information, the announcements of the merger can influence the stock price immediately. Therefore, prior to the announcement date, managers of the acquiring firms should manipulate reported earnings upward to maximize the benefits from earnings management.

Previous articles have documented that in a stock for stock merger, managers of the acquiring firms are more likely to increase their stock price in order to reduce the cost of buying the target (Erickson \& Wang, 1999). For a stock for stock merger, the acquiring firm purchases the target firm with its stock. When the transaction is completed, the target firm receives a specified amount of acquiring firm stock with the market value matching target firm purchase price. Therefore, if the acquiring firm's stock price is higher on the agreement date, the acquiring firm issues fewer number of shares to purchase the target firms. The relationship between the acquiring firm stock price and shares issued in the transaction provides incentives for the mangers in the acquiring firm to issue fewer shares. First, existing shareholders prefer a higher price to minimize the impact of earnings dilution. Second, existing shareholders are less likely to accept diluted voting power and control over the company. Third, the higher the value of the acquiring firm's stock, the lower the cost to acquire the target firm. Therefore, both empirical and theoretical evidence shows that managers in acquiring firms are more likely to manipulate their earnings in stock mergers. As discussed above, firms can use one or all three earnings management methods. Therefore, this leads to the following hypothesis:

Ha: The acquiring firm uses accrual-based earnings management (discretional accrual) in the year of a stock for stock merger.

Hb: The acquiring firm uses real earnings management in the year of a stock for stock merger.

Hc: Classification shifting is more pervasive for the acquiring companies in the year of a stock for stock merger.

\section{RESEARCH DESIGN}

\section{Accrual-based Earnings Management}

For accrual-based earnings management, this study uses Jones (1991) model, which indicates that the accruals of each company of the same country should be correlated with the change of sales as well as property, plant and equipment accounts. TA is the total accrual, which is the difference between earnings before extraordinary items and discontinued operations and operating cash flows.

$$
\frac{\mathrm{TA}_{\mathrm{it}}}{\text { Assets }_{\mathrm{i}, \mathrm{t}-1}}=\mathrm{k}_{1} \frac{1}{\text { Assets }_{\mathrm{i}, \mathrm{t}-1}}+\mathrm{k}_{2} \frac{\Delta \text { Sales }_{\mathrm{it}}}{\text { Assets }_{\mathrm{i}, \mathrm{t}-1}}+\mathrm{k}_{3} \frac{\text { PPE }_{\mathrm{it}}}{\text { Assets }_{\mathrm{i}, \mathrm{t}-1}}+\varepsilon_{\mathrm{it}}
$$

From the equation above, the coefficients of $\mathrm{k} 1, \mathrm{k} 2$, and $\mathrm{k} 3$ can be estimated. Using the estimated coefficients, I calculate the expected accruals $\left(\mathrm{NA}_{t}\right)$ for each company.

$$
\mathrm{NA}_{\mathrm{it}}=\widehat{\mathrm{K}}_{1} \frac{1}{\text { Assets }_{\mathrm{i}, \mathrm{t}-1}}+\widehat{\mathrm{K}}_{2} \frac{\Delta \text { Sales }_{\mathrm{it}}}{\text { Assets }_{\mathrm{i}, \mathrm{t}-1}}+\widehat{\mathrm{K}}_{3} \frac{\text { PPE }_{\mathrm{it}}}{\text { Assets }_{\mathrm{i}, \mathrm{t}-1}}+\varepsilon_{\mathrm{it}}
$$

The proxy for accrual-based earnings management in this paper is the discretional accruals, the difference between the total accruals and expected accruals.

$$
\mathrm{DA}_{\mathrm{it}}=\frac{\mathrm{TA}_{\mathrm{it}}}{\text { Assets }_{\mathrm{i}, \mathrm{t}-1}}-\mathrm{NA}_{\mathrm{it}}
$$


Based on previous studies, each variable is deflated by lagged total asset in order to mitigate the heteroskedasticity issue.

Following Gunny (2010), this study uses the following equation to capture the relationship between discretional accrual and stock for stock merger.

$$
\mathrm{DA}_{\mathrm{it}}=\mathrm{k}_{1}+\mathrm{k}_{2} \text { Stock Merger }_{\mathrm{it}}+\mathrm{k}_{3} \text { MTB }_{\mathrm{it}}+\mathrm{k}_{4} \text { LNSIZE }_{\mathrm{it}}+\mathrm{k}_{5} \text { ROA }_{\mathrm{it}}+\varepsilon_{\mathrm{it}}
$$

where Stock Merger is a dummy variable with a value of one if the acquiring firm involves in a stock for stock merger in a certain year, and MTB represents market to book ratio. ROA and LNSIZE represent return on assets and the natural logarithm of total assets respectively

If firms employ the accrual-based earnings management method, the discretional accrual will be higher for those firms. Thus $\mathrm{k}_{2}$ should be positive and significant.

\section{Real Earnings Management}

For the real earnings management, following Bhojraj et al. (2010), this study examines the discretionary expenditures, which are the sum of research expenses, advertising expenses and selling, general and administrative expense. Based on Roychowdhury's (2006) paper, discretional expenses (DISX) is expressed as a linear function of change in sales and current sales.

$$
\frac{\text { DISX }_{i t}}{\text { Assets }_{i, t-1}}=k_{1}+k_{2} \frac{1}{\text { Assets }_{i, t-1}}+k_{3} \frac{\text { Sales }_{i t-1}}{\text { Assets }_{i, t-1}}+\varepsilon_{i t}
$$

The abnormal DISX is measured by the difference between actual DISX and estimated DISX by using above equation.

Same as the equation to estimate the relationship between accrual-based earnings management and a stock for stock merger, this study uses the following equation to capture the relationship between abnormal discretional expenses and stock for stock merger.

$$
\text { Abnormal DISX }_{i t}=k_{1}+k_{2} \text { Stock Merger }_{i t}+k_{3} \text { MTB }_{i t}+k_{4} \text { LNSIZE }_{i t}+k_{5} \text { ROA }_{i t}+\varepsilon_{i t}
$$

If firms manage their earnings upward by reducing the cash-based expenses, the abnormal discretional expense will be lower for those firms. Thus $\mathrm{k}_{2}$ should be negative and significant.

\section{Classification Shifting within the Income Statements}

For the classification shifting method, following Mcvay (2006) and Fan et al. (2010), I use the following regression to estimate core earnings (CE):

$$
\mathrm{CE}_{\mathrm{it}}=\mathrm{k}_{0}+\mathrm{k}_{1} \mathrm{CE}_{\mathrm{i}, \mathrm{t}-1}+\mathrm{k}_{2} \mathrm{ATO}_{\mathrm{it}}+\mathrm{k}_{3} \mathrm{ACCRUALS}_{\mathrm{i}, \mathrm{t}-1}+\mathrm{k}_{4} \Delta \mathrm{SALES}_{\mathrm{it}}+\mathrm{k}_{5} \mathrm{NEG}_{-} \Delta \mathrm{SALES}_{\mathrm{it}}+\varepsilon_{\mathrm{it}}
$$

Regressions are estimated by industry and fiscal year, where industries are classified following Fama and French (1997).

$\mathrm{ATO}_{i t}$ is the asset turnover ratio. ACCRUALS $\mathrm{A}_{\mathrm{it}-1}$ is the prior-year operating accruals. $\triangle$ SALES $\mathrm{S}_{\mathrm{it}}$ is change in sales in year $\mathrm{t}$, while NEG_LSALES ${ }_{\mathrm{it}}$ is a percent change in sales if sale growth in year $\mathrm{t}$ is less than 0 , and 0 otherwise.

The unexpected core earnings (UE_CE) are the difference between the estimated core earnings and the real core earnings. To test the whether firms employ the classification shifting method, the following equation is used: 


$$
\text { UE_CE } E_{\mathrm{it}}=\alpha_{0}+\alpha_{1} \% \mathrm{SI}_{\mathrm{it}}+\alpha_{2} \text { Stock Mergerit }+\alpha_{3} \text { Stock Merger }_{\mathrm{it}} * \% \mathrm{SI}_{\mathrm{it}}+\varepsilon_{\mathrm{it}}
$$

where $\% \mathrm{SI}_{\text {it }}$ is the total income - decreasing special items from the financial statements. If managers classify core expenses as special item, one should expect a positive and significant $\alpha_{3}$ in the regression above.

\section{SAMPLE AND DATA}

In order to be consistent for the three methods of earnings management, all the financial data are from the Compustat for the period from 1988 to 2010.Firm-years observations should satisfy the following criteria: (1) each firm-year observation should have sufficient data for the regression model (i.e. no missing value); (2) observations should have sales greater than $\$ 1$ million to avoid the creation of outliers; (3) observations should not have fiscal-year-end change to ensure that years are comparable; and (4) there should be at least 15 observations per industry per fiscal year for regression purpose. The sample size for discretional expenses method is much smaller in that I exclude firm year observation with no available data for all three items (researching, advertising and administrative expenses) in the discretional expenses. Table 1 provides detailed information about the sample selection process for discretional accrual regression. For the other two methods, I follow the same procedures.

\section{TABLE 1}

\section{SAMPLE SELECTION PROCESS FOR CLASSIFICATION SHIFT REGRESSION}

\begin{tabular}{l|l}
\hline Annual Compustat (1988-2010) & Firm-years \\
& 257,640 \\
Less observations with zero values for sales & $(26,473)$ \\
Less observations with missing value (i.e. missing total asset or sales) & $(61,437)$ \\
Less observations with sales less than \$1 million & $(5,786)$ \\
Less observations with changes in fiscal year & $(467)$ \\
Less observations with inadequate lagged values & $(21,545)$ \\
Less observations in the industry with which there is less than 15 observation in given & \\
year & $(1,389)$ \\
\hline Final sample (firm-years) & 140,543 \\
\hline
\end{tabular}

The industries classification follows Fama and French (1997). They use four-digit SIC codes to assign firms to 48 industries. The table 2 presents the industry membership for the sample. The largest membership in the sample belongs to the business service industry, which comprises approximately 11 percent of the sample firms. Retail firms represent approximately 6 percent of the sample, while Petroleum firms represent about 5 percent of the sample. Three industries do not have any firm observation in that each industry should have a minimum of 15 observations per fiscal year. The industries without any observations are tobacco, ships and defense industries. The percentage for the remaining industries ranges from 0.09 percent to 4 percent. 
TABLE 2

INDUSTRY MEMBERSHIP

\begin{tabular}{|c|c|c|}
\hline Industry Name & Number of firms & Percent of Total \\
\hline Agriculture & 284 & $0.31 \%$ \\
\hline Food Products & 1,726 & $1.88 \%$ \\
\hline Candy \& Soda & 85 & $0.09 \%$ \\
\hline Beer \& Liquor & 207 & $0.23 \%$ \\
\hline Tobacco Products & 0 & $0.00 \%$ \\
\hline Recreation & 884 & $0.96 \%$ \\
\hline Entertainment & 1,707 & $1.86 \%$ \\
\hline Books & 746 & $0.81 \%$ \\
\hline Consumer Goods & 1,765 & $1.92 \%$ \\
\hline Apparel & 1,516 & $1.65 \%$ \\
\hline Healthcare & 1,878 & $2.05 \%$ \\
\hline Medical Equipment & 3,305 & $3.60 \%$ \\
\hline Drugs & 3,539 & $3.86 \%$ \\
\hline Chemicals & 1,673 & $1.82 \%$ \\
\hline Rubber and Plastic Products & 910 & $0.99 \%$ \\
\hline Textiles & 464 & $0.51 \%$ \\
\hline Construction Materials & 1,850 & $2.02 \%$ \\
\hline Construction & 1,216 & $1.33 \%$ \\
\hline Steel & 1,444 & $1.57 \%$ \\
\hline Fabricated Products & 371 & $0.40 \%$ \\
\hline Machinery & 3,310 & $3.61 \%$ \\
\hline Electrical Equipment & 1,572 & $1.71 \%$ \\
\hline Autos & 1,435 & $1.56 \%$ \\
\hline Aircraft & 408 & $0.44 \%$ \\
\hline Ships & 0 & $0.00 \%$ \\
\hline Defense & 0 & $0.00 \%$ \\
\hline Gold & 730 & $0.80 \%$ \\
\hline Mines & 472 & $0.51 \%$ \\
\hline Coal & 52 & $0.06 \%$ \\
\hline Oil & 4,400 & $4.80 \%$ \\
\hline Utilities & 3,154 & $3.44 \%$ \\
\hline Communication & 3,295 & $3.59 \%$ \\
\hline Personal Services & 1,056 & $1.15 \%$ \\
\hline Business Services & 9,972 & $10.87 \%$ \\
\hline Computers & 4,371 & $4.76 \%$ \\
\hline Electronic Equipment & 6,161 & $6.71 \%$ \\
\hline Measuring Equipment & 2,334 & $2.54 \%$ \\
\hline Business Supplies & 1,327 & $1.45 \%$ \\
\hline Shipping Containers & 117 & $0.13 \%$ \\
\hline
\end{tabular}




\begin{tabular}{|c|c|c|}
\hline Industry Name & Number of firms & Percent of Total \\
\hline Transportation & 2,780 & $3.03 \%$ \\
\hline Wholesale & 4,132 & $4.50 \%$ \\
\hline Retail & 5,190 & $5.66 \%$ \\
\hline Restaurants, Hotels, Motels & 2,099 & $2.29 \%$ \\
\hline Banking & 2,725 & $2.97 \%$ \\
\hline Insurance & 610 & $0.66 \%$ \\
\hline Real Estate & 1,029 & $1.12 \%$ \\
\hline Trading & 2,564 & $2.79 \%$ \\
\hline Other & 893 & $0.97 \%$ \\
\hline Total & 91,758 & $100.00 \%$ \\
\hline
\end{tabular}

To be consistent, the stock for stock merger firm sample covers the same period from 1988 to 2010 . The sample from SDC platinum database are chosen based on the following criteria: (1) The merger was successfully completed; (2) the transaction is either a pure stock swap; (3) the acquirer owns $100 \%$ of the target after the merger. The final sample consists of 3,468 successful mergers.

\section{RESULTS}

Table 3 presents the correlation among different dependent and independent variables used in regressions. There is a significant negative relationship between Discretional Accrual and Abnormal DISX. This indicates that firms may involve in both earnings management methods. For the other controlling variables, most of them are significantly related to UE_CE, Discretional Accrual, and Abnormal DISX expect for MTB, which is only significantly related to Abnormal DISX.

TABLE 3

PEARSON (SPEARMAN) ABOVE (BELOW) THE DIAGONAL CORRELATION TABLE

\begin{tabular}{|c|c|c|c|c|c|c|}
\hline & UE_CE & $\begin{array}{l}\text { Discretional } \\
\text { Accrual }\end{array}$ & $\begin{array}{l}\text { Abnormal } \\
\text { DISX }\end{array}$ & MTB & LNSIZE & ROA \\
\hline UE_CE & & 0.0945 & -0.0401 & $-0.0040^{\#}$ & 0.0266 & 0.4120 \\
\hline $\begin{array}{l}\text { Discretional } \\
\text { Accrual }\end{array}$ & 0.0814 & & -0.0168 & $0.0081^{\#}$ & -0.0178 & 0.1428 \\
\hline $\begin{array}{l}\text { Abnormal } \\
\text { DISX }\end{array}$ & -0.0527 & -0.1699 & & -0.0773 & -0.0739 & -0.0403 \\
\hline MTB & 0.0602 & 0.0732 & -0.1066 & & 0.0771 & $-0.0131^{!}$ \\
\hline LNSIZE & 0.0587 & $0.0097^{\#}$ & -0.1739 & 0.1527 & & -0.0131 \\
\hline ROA & 0.3488 & 0.1745 & -0.1211 & 0.2406 & 0.2096 & \\
\hline
\end{tabular}

All coefficients are significant at 5\% level, except \# indicates not significant and ! Indicates significance at $10 \%$ level.

UE_CE is the unexpected core earnings, which is calculated deviations from the estimated values form the following industry-year regression:

$$
C E_{t}=K_{1}+K_{2} C E_{t-1}+K_{3} \text { Accrual }_{t-1}+K_{3} A T O_{t}+K_{4} \Delta \text { Sales }_{t}+K_{5} \Delta \text { Sales }_{t}
$$

Discretionary Accruals are estimated as deviations from the estimated values form the Jones (1991) model: 


$$
\frac{\mathrm{TA}_{i t}}{\operatorname{Assets}_{\mathrm{i}, \mathrm{t}-1}}=\mathrm{k}_{1} \frac{1}{\operatorname{Assets}_{\mathrm{i}, \mathrm{t}-1}}+\mathrm{k}_{2} \frac{\Delta \text { Sales }_{\text {it }}}{\operatorname{Assets}_{\mathrm{i}, \mathrm{t}-1}}+\mathrm{k}_{3} \frac{\text { PPE }_{\mathrm{it}}}{\operatorname{Assets}_{\mathrm{i}, \mathrm{t}-1}}+\varepsilon_{\mathrm{it}}
$$

Abnormal discretionary expenses are calculated deviations from the estimated values form the following industry-year regression:

$\frac{\operatorname{DISX}_{i t}}{\operatorname{Assets}_{i, t-1}}=k_{1}+k_{2} \frac{1}{\operatorname{Assets}_{i, t-1}}+k_{3} \frac{\text { Sales }_{i t-1}}{\text { Assets }_{i, t-1}}+\varepsilon_{i t}$

where DISX are discretionary expenses, defined as the sum of advertising expenses (XAD), R\&D expenses (XRD), and SG\&A (XSGA)

MTB is the market to book, which is the market value of equity divided by the book value of equity. ROA is return on assets, which is net income before extraordinary items scaled by lagged assets. LNSIZE is the natural logarithm of total assets.

All variables are winsorized at the $1 \%$ and $99 \%$ percentiles before the correlation analysis.

Table 4 captures the relationship between stock for stock merges and discretional accruals. After controlling for the firm size, operating performance and market valuation, this study shows that there is a significant relationship between discretional accruals and stock for stock mergers. The coefficient of Stock Merger is 0.1402 and significant. This indicates that the acquiring firms have significant income increasing accruals in the year of mergers. The finding is consistent with the previous research (Erickson \& Wang, 1999; Louis, 2004) in that acquiring firms manage earnings upward in the year of stock for stock mergers. This is also consistent with the hypothesis regarding the accrual-based earnings management (Ha).

TABLE 4

IMPACT OF STOCK FOR STOCK MERGERS ON DISCRETIONAL ACCRUAL

\begin{tabular}{ll}
\hline Variables & $\begin{array}{l}\text { Abnormal } \\
\text { Accrual }\end{array}$ \\
\hline Intercept & 0.3178 \\
& {$[34.18]^{* * *}$} \\
Stock Merger & 0.1402 \\
& {$[5.66]^{* * *}$} \\
MTB & 0.0008 \\
& {$[1.37]$} \\
LNSIZE & -0.0330 \\
ROA & {$[-20.03]^{* * *}$} \\
& 0.2026 \\
$\mathrm{~N}$. & {$[44.86]^{* * *}$} \\
Adj- $\mathrm{R}^{2}$ & 140,543 \\
\hline
\end{tabular}

$\frac{\text { Adj- } \mathrm{R}^{2}}{1.40 \%}$
significance at the $1 \%, 5 \%, 10 \%$ level (two-tailed) respectively.

Stock Merger is a dummy variable with value one if the firm acquires firm though a stock for stock merger in certain year. MTB is the market to book, which is the market value of equity divided by the book value of equity. 
ROA is return on assets, which is net income before extraordinary items scaled by lagged assets. LNSIZE is the natural logarithm of total assets.

Discretionary Accruals are estimated as deviations from the estimated values form the Jones (1991) model:

$$
\frac{\mathrm{TA}_{\mathrm{it}}}{\text { Assets }_{\mathrm{i}, \mathrm{t}-1}}=\mathrm{k}_{1} \frac{1}{\text { Assets }_{\mathrm{i}, \mathrm{t}-1}}+\mathrm{k}_{2} \frac{\Delta \text { Sales }_{\mathrm{it}}}{\text { Assets }_{\mathrm{i}, \mathrm{t}-1}}+\mathrm{k}_{3} \frac{\text { PPE }_{\mathrm{it}}}{\operatorname{Assets}_{\mathrm{i}, \mathrm{t}-1}}+\varepsilon_{\mathrm{it}}
$$

Table 5 shows the relationship between stock for stock merges and abnormal discretional expenses. In order to manipulate the net income upward, managers need to use their discretion to reduce the expenses related to research, advertising and other operations. The finding shows that the coefficient of Stock Merger is -0.1711 with a t-stat of -3.72 . Therefore, in the year of mergers, the acquiring firms manipulate their net income upward by cutting the expenditures on research, advertising and administrative operations. No previous research addressing the relationship between real earnings management and stock for stock mergers. This study provides empirical evidence indicating such relationships. This is also consistent with $\mathrm{Hb}$.

TABLE 5

IMPACT OF STOCK FOR STOCK MERGERS ON CASH-BASED EXPENDITURES

\begin{tabular}{ll}
\hline Variables & $\begin{array}{l}\text { Abnormal } \\
\text { discretionary } \\
\text { expenses }\end{array}$ \\
\hline Intercept & 0.1445 \\
& {$[7.99]^{* * *}$} \\
Stock Merger & -0.1711 \\
& {$[-3.72]^{* * *}$} \\
MTB & -0.0072 \\
& {$[-6.49]^{* * *}$} \\
LNSIZE & -0.0373 \\
& {$[-11.13]^{* * *}$} \\
ROA & -0.1417 \\
& {$[-16.26]^{* * *}$} \\
\hline N. & 26,046 \\
Adj- ${ }^{2}$ & $2.29 \%$ \\
\hline T-statistics are in brackets and $* * *, * *, *$ indicate statistical \\
significance at the $1 \%, 5 \%, 10 \%$ level (two-tailed) respectively.
\end{tabular}

Stock Merger is a dummy variable with value one if the firm acquires firm though a stock for stock merger in certain year. MTB is the market to book, which is the market value of equity divided by the book value of equity. ROA is return on assets, which is net income before extraordinary items scaled by lagged assets. LNSIZE is the natural logarithm of total assets.

Abnormal discretionary expenses are calculated deviations from the estimated values form the following industry-year regression:

$$
\frac{\operatorname{DISX}_{i t}}{\operatorname{Assets}_{i, t-1}}=k_{1}+k_{2} \frac{1}{\text { Assets }_{i, t-1}}+k_{3} \frac{\text { Sales }_{i t-1}}{\text { Asset }_{i, t-1}}+\varepsilon_{i t}
$$


where DISX are discretionary expenses, defined as the sum of advertising expenses (XAD), R\&D expenses (XRD), and SG\&A (XSGA).

Table 6 shows the regression results for unexpected core earnings on special items as a percent of sales and stock for stock merger. Fan et al.(2010) modified McVay's model by excluding contemporaneous accruals to avoid introducing the potential bias and attempt to better control for the performance effect. Consistent with previous research (Fan et al, 2010), the coefficient for SI\% is negative. This indicates that the magnitude and frequency of income-decreasing special items are markedly higher among firms experiencing poor performance. Thus, there is a negative relation between earnings performance and the amount of income-decreasing special items. After introducing the dummy for stock for stock merger firms, this study focuses on the interaction between stock for stock mergers and special items. If the acquiring firms employ the classification shifting method, the expected sign for the interaction should be positive. This means that for stock merger firm should make the relationship between unexpected core earnings and special item less negative. However, the coefficient of interaction is -0.0510 with $\mathrm{T}$-stat of -10.01 . This indicates that for stock for stock merger firms, the relationship between unexpected core earnings and special item is even more negative. Therefore, there is no evidence that stock for stock mergers firms employ the classification shifting method in the year of mergers. This is contrary to the hypothesis regarding classification shifting $(\mathrm{Hc})$.

\section{TABLE 6 \\ IMPACT OF SPECIAL ITEMS AS A PERCENT OF SALES AND STOCK FOR STOCK MERGER}

\begin{tabular}{ll}
\hline Variables & UE_CE $E_{t}$ \\
\hline Intercept & 0.0016 \\
& {$[1.95]^{*}$} \\
\%SI & -0.0108 \\
& {$[-13.95]^{* * *}$} \\
Stock Merger & -0.0497 \\
& {$[-8.93]^{* * *}$} \\
\%SI*Stock Merger & -0.0510 \\
& {$[-10.01]^{* * *}$} \\
\hline N. & 122,514 \\
Adj- $\mathrm{R}^{2}$ & $1.70 \%$ \\
\hline
\end{tabular}

T-statistics are in brackets and $* * *, * * *$ indicate statistical significance at the $1 \%, 5 \%, 10 \%$ level (two-tailed) respectively. Unexpected core earnings are calculated deviations from the estimated values form the following industry-year regression:

$$
C E_{t}=K_{1}+K_{2} C E_{t-1}+K_{3} \text { Accrual }_{t-1}+K_{3} \text { ATO }_{t}+K_{4} \Delta \text { Sales }_{t}+K_{5} \Delta \text { Sales }_{t}
$$

$\% \mathrm{SI}_{\mathrm{it}}$ is the total income - decreasing special items from the financial statements and Stock Merger is a dummy variable with value one if the firm acquires firm though a stock for stock merger in certain year.

After examining the relationship between stock mergers and three earnings management methods, I find that acquiring firms in the year of mergers are more likely to use only accrual-based and real earnings management. Therefore, further analysis is restricted to only accrual-based and real earnings management. I then develop an aggregate earnings quality index by combining the accrual-based and real earnings management together. This study compares stock merger firms with low earnings quality and stock merger firms with high earnings quality in terms of operating and stock market performance. 
This study uses EarningsQuality as the aggregate earnings management index, which takes into account discretionary accruals and abnormal discretional expenses. EarningsQuality is a ranking from zero to two with a firm receiving one point if abnormal accruals (abnormal discretional expenses) are below (above) the median level of all firms in a given year. No point is awarded for missing variables. Therefore, a firm with a rank of 2 would have scaled abnormal accruals below the median and scaled abnormal discretional expenses above the median in a given year. "High" EarningsQuality is defined as any firm with a rank of two. "Low" EarningsQuality is defined as a firm with a rank of zero.

Table 7 presents the findings for operating performance of stock for stock merger firms based on earnings quality. The high earnings quality firms outperform the low earnings quality firms in terms of return on asset for up to three years. In year 3, the difference between these two groups of firms becomes insignificant. Thus, higher earning quality lead to better operating performance.

\section{TABLE 7 \\ CURRENT AND FUTURE OPERATING PERFORMANCE OF FIRMS BASED ON EARNINGS QUALITY}

\begin{tabular}{lllll}
\hline & $\mathrm{ROA}_{\mathrm{t}}$ & $\mathrm{ROA}_{\mathrm{t}+1}$ & $\mathrm{ROA}_{\mathrm{t}+2}$ & $\mathrm{ROA}_{\mathrm{t}+3}$ \\
\hline Low & & & \\
EarningsQuality & 0.7443 & 0.7931 & 0.8463 & 0.8699 \\
High & & & \\
EarningsQuality & 1.1528 & 1.2006 & 1.1176 & 0.9843 \\
Difference & $-0.4085^{* * *}$ & $-0.4074 * * *$ & $-0.2713 * * *$ & -0.1144 \\
& & & \\
\hline $\mathrm{t}$-stat & -5.05 & -4.66 & -3.17 & -1.25 \\
\hline$* * * * *$ indicate statistical significance at the $1 \%, 5 \%, 10 \%$ level (two-tailed) respectively.
\end{tabular}

This table examines ROA, defined as income (NI), divided by total assets (AT).

EarningsQuality is a ranking from zero to two with a firm receiving one point if abnormal accruals (abnormal discretional expenses) are below (above) the median level of all firms in a given year. No point is awarded for missing variables. Therefore, a firm with a rank of 2 would have scaled abnormal accruals below the median and scaled abnormal discretional expenses above the median in a given year. "High" EarningsQuality is defined as any firm with a rank of two. "Low" EarningsQuality is defined as a firm with a rank of zero.

I then compare the future stock performance of low earnings firms with the on high earnings quality firms. Table 8 shows the comparison in terms of cumulative abnormal returns (CARs) by using both equal-weighted (EW) and value-weighted (VW) market returns as benchmark for 3-, 6-, 12-, 24- and 36months after the merger announcement date. This study chooses CARs instead of buy-and-hold abnormal returns (BHARs) because both Fama (1998) and Mitchell and Stafford (2000) advocate using cumulative abnormal returns (CARs) rather than BHARs because BHARs can magnify abnormal performance by compounding. Cumulative abnormal return for firm i is measured as:

$$
\operatorname{CAR}_{\mathrm{i}}=\sum_{\mathrm{t}=1}^{\mathrm{T}}\left(\mathrm{R}_{\mathrm{it}}-\mathrm{R}_{\text {Benchmark }, \mathrm{t}}\right)
$$

Table 8 shows low earnings quality firms benefit from the earnings management behaviors in the short term in that those firms with low earnings quality have higher abnormal returns than the high earnings quality firms in the first 6 months in both EW and VW adjusted CARs. However, the difference starts to disappear 12 months and 24 months after the merger announcement date. When it comes to 36- 
month horizon, both EW and VW CARs indicate high earnings quality firms start to perform marginally better than the low earnings quality firms.

TABLE 8

FUTURE STOCK PERFORMANCE BASED ON EARNINGS QUALITY

Cumulative Abnormal Returns (CARs)

Month

3

Low EarningsQuality

High EarningsQuality

Difference

t-stat

6 Low EarningsQuality

High EarningsQuality

Difference

t-stat

12 Low EarningsQuality

High EarningsQuality

Difference

t-stat

24 Low EarningsQuality

High EarningsQuality

Difference

t-stat

36
Low EarningsQuality

High EarningsQuality

Difference
Equal-Weighted

0.3277

$-0.0984$

$0.4261 * * *$

2.60

0.3139

$-0.1615$

$0.4754 * *$

2.50

0.2164

$-0.0344$

0.2508

1.00

$-0.0688$

0.0355

$-0.1043$

$-0.34$

0.0257

0.6729

$-0.6472 *$
Value-Weighted

0.4023

0.0527

$0.3496^{* * *}$

2.06

0.3987

0.0237

$0.375^{*}$

1.93

0.3473

0.2107

0.1366

0.53

0.2527

0.3855

$-0.1327$

$-0.42$

0.5347

1.1247

-0.5901 *

$-1.67$

***, $* *, *$ indicate statistical significance at the $1 \%, 5 \%, 10 \%$ level (two-tailed) respectively.

EarningsQuality is a ranking from zero to two with a firm receiving one point if abnormal accruals (abnormal discretional expenses) are below (above) the median level of all firms in a given year. No point is awarded for missing variables. Therefore, a firm with a rank of 2 would have scaled abnormal accruals below the median and scaled abnormal discretional expenses above the median in a given year. "High" EarningsQuality is defined as any firm with a rank of two. "Low" EarningsQuality is defined as a firm with a rank of zero.

Cumulative abnormal return for firm i is measured as:

$$
C A R_{i}=\sum_{t=1}^{T}\left(R_{i t}-R_{\text {Benchmark }, t}\right)
$$

Both EW and VW market returns are used as benchmark return. 
The results also indicate that the stock performance of low earnings quality firms are better 3 or 6 months after the merger announcement date. But the performance starts to deteriorate after that. Both VW adjusted CARs and EW adjusted CARs a downward trend in stock performance after the merger. On the other hand, the high quality firms are in the upward trend in terms of CARs after the merger announcement date. Louis (2004) finds significantly negative correlation between long-term performance and abnormal accruals of the stock for stock acquirers. This is due to reversal of the effects of pre-merger earnings management. I find the similar results as CARs move downward after the merger announcement date. However, for the high earnings quality firms, the reversal impact is very small and they are able to move out of the reversal impact easily comparing with the low earnings quality firms. This also indicates that earnings management by manipulating the accrual upward or cutting the discretional expenses is myopia behavior.

\section{CONCLUSION}

This study investigates the relationship between stock for stock mergers and three earnings management methods: (1) accrual-based earnings management; (2) real earnings management; and (3) misclassification of items within the income statements. The results show that stock for stock merger firms in the year of mergers are more likely to use accrual-based and real earnings management instead of classification shifting.

This study then uses only accrual-based earnings management and real earnings management to develop an aggregate index. I then compare the operating and stock market performance. The results show that the high earnings quality firms outperform the lower earnings quality firms in terms of return on asset. Moreover, for the low earnings quality firms, their stock performance is better 3 or 6 months after the merger announcement date, so they benefit from high earnings management behaviors in the short term. But the performance starts to deteriorate after that. The results also show that high earnings quality firms can move out of the reversal impact easily comparing with the low earnings quality firms. In addition, the study provides evidence that earnings management is a myopia behavior, which has a negative impact on future performance. 


\section{REFERENCES}

Bartov, E., Givoly, D., \& Hayn, C. (2002). The rewards to meeting or beating earnings expectations. Journal of Accounting and Economics, 33(2), 173-204.

Bens, D. A., Nagar, V., \& Wong, M. H. F. (2002). Real investment implications of employee stock option exercises. Journal of Accounting Research, 40(2), 359-393.

Bhojraj, S., Hribar, P., Picconi,M., \& Mcinnis, J. (2009). Making sense of cents: An examination of firms that marginally miss or beat analyst forecasts. The Journal of Finance, 64(5), 2361-2388.

Botsari, A., \& Meeks, G. (2008). Do acquirers manage earnings prior to a share for share bid? Journal of Business Finance \& Accounting, 35(5-6), 633-670.

Dechow, P. M., \& Sloan, R. G. (1991). Executive incentives and the horizon problem: An empirical investigation. Journal of Accounting and Economics, 14(1), 51-89.

Erickson, M., \& Wang, S. (1999). Earnings management by acquiring firms in stock for stock mergers. Journal of Accounting and Economics, 27(2), 149-176.

Fama, E. F. (1998). Market efficiency, long-term returns, and behavioral finance. Journal of Financial Economics, 49(3), 283-306.

Fama, E. F., \& French, K. R. (1997). Industry costs of equity. Journal of Financial Economics, 43(2), 153-193.

Fan, Y., Barua, A., Cready, W. M., \& Thomas, W. B. (2010). Managing earnings using classification shifting: Evidence from quarterly special items. Accounting Review, 85(4), 1303-1323.

Gunny, K. A. (2010). The relation between earnings management using real activities manipulation and future performance: Evidence from meeting earnings benchmarks. Contemporary Accounting Research, 27(3), 855-888.

Healy, P. M. (1985). The effect of bonus schemes on accounting decisions. Journal of Accounting \& Economics, 7(1), 85-107.

Healy, P. M., \& Wahlen, J. M. (1999). A review of the earnings management literature and its implications for standard setting. Accounting Horizons, 13(4), 365-383.

Jones, J. J. (1991). Earnings management during import relief investigations. Journal of Accounting Research, 29(2), 193-228.

Louis, H. (2004). Earnings management and the market performance of acquiring firms. Journal of Financial Economics, 74(1), 121-148.

McVay, S. E. (2006). Earnings management using classification shifting: An examination of core earnings and special items. Accounting Review, 81(3), 501-531.

Mitchell, M. L., \& Stafford, E. (2000). Managerial decisions and long-term stock price performance. Journal of Business, 73(3), 287.

Phillips, J., Morton Pincus, \& Rego, S. O. (2003). Earnings management: New evidence based on deferred tax expense. The Accounting Review, 78(2), 491-521.

Roychowdhury, S. (2006). Earnings management through real activities manipulation. Journal of Accounting \& Economics, 42(3), 335-370. 